they offer many advantages, and more precise knowledge and methods of control may overcome the hesitancy of responsible authorities.

The first and last sections of the report are widely apart in position and closely related in theme. The first-which includes in one place an account of a most interesting survey of the real loads on office floors-presents the results of a comparative examination of the regulations controlling steel frame building construction in Great Britain, the Dominions, and in some foreign countries. The general comparison of regulations displays extraordinary variations in such matters as floor loads and wind pressure allowances, and in the clauses governing the proportioning of members. On practically every page of this section there is evidence of the confusion and variety that can be introduced by autocratic authorities at work independently.

The last part presents the recommendations of the Committee for a code of practice governing the general use of structural steel. In view of the fact that these recommendations accompany a first progress report, there is always the probability of future amendment in the light of subsequent data. It is understood, however, that the code will be explicitly referred to in the model by-laws to be issued by the Ministry of Health. This may be taken as an augury of the full recognition that will be accorded the completed work of so influential and representative a Committee, the first report of which displays a breadth of vision and power of planning that promises ultimate success in a difficult task.

\title{
Obituary
}

\section{Prof. P. N. Kryloff}

THE name of Porphirii Nikitich Kryloff, professor of botany and plant geography at the University of Tomsk, who died on Dec. 27, 1931, at the age of eighty-one years, will always be associated with the exploration of the Siberian flora. Born of a poor family, Kryloff had to earn his living ever since he left his school, still a boy in his teens. Becoming an apprentice in a chemist's shop at Perm, young Kryloff became seriously interested in chemistry and medicinal plants, and devoted his spare time to studying for an examination to obtain a pharmacist's degree at the University of Kazan, and to the collection of plants. After obtaining the degree, he continued to work as a dispensing chemist.

The botanical exploration of the Perm province and of the Ural Mountains was now Kryloff's main and only recreation. With very limited resources, often on foot, he wandered over that enormous area, and produced a series of papers on its flora, which was then very little known. In 1874 it became possible for Kryloff to abandon his old profession and to devote himself entirely to botany, by taking a modest appointment as a "learned gardener" at the University of Kazan. While at Kazan, he made an extensive study of the flora of that province, but dreamed of botanical explorations in wider and less-known regions.

At the foundation of the new University of Tomsk, the first scientific centre in Siberia, Kryloff did not hesitate to take there the same post of ' learned gardener', becoming later the keeper of the botanical museum, which he built up himself. A new, and practically virgin, field was now open before Kryloff, and he threw himself into this congenial task with his usual energy. Most of western Siberia, the Altai Mountains, and northern Mongolia offered an inexhaustible supply of most interesting problems in the systematics and distribution of plants. An enormous herbarium, comprising more than 200,000 specimens of plants, was the result of the journeys of Kryloff himself and of his students, who were attracted by his unaffected and enthusiastic love of Nature. In systematic studies in the herbarium Kryloff was as thorough as in collecting. He prepared detailed descriptions of all the species known to occur in the regions visited, and maps showing areas of their distribution elsewhere. This formed the basis of his well-known "Flora of Altai and of the Tomsk Province", published in seven volumes between 1901 and 1914. The importance of this work for the study of the flora of temperate Asia and even of Europe cannot be overestimated, and it is not surprising that it was soon out of print.

In 1913 Kryloff was invited to take the post of botanist in charge of the Siberian herbarium at the Academy of Sciences in St. Petersburg but the economic difficulties of living in the capital during the revolution induced him to return in 1917 to Tomsk, where he became professor of botany. Here he set himself a new and a very ambitious task of preparing a complete flora of western Siberia, from the Urals to the Yenisei and from the Arctic Ocean to central Asia. It may seem almost unbelievable, but the work was completed, with the usual masterfulness, within six years, after which several years were spent in endless efforts to find the funds for its publication. It was only in 1926 that the great "Flora of Western Siberia " began to come out in parts, and is still continuing to be published.

Prof. Kryloff's interests were not purely floristic, but mainly phytogeographical, and his exceptional first-hand knowledge of Siberia and its plants enabled him to produce a series of most valuable papers on the distribution and past history of the Siberian flora. One of the points particularly well brought out by Kryloff's work was the existence in the Altai Mountains of an ancient centre of the origin of many typical Siberian plants, which later migrated widely and reached European countries. The foundation of a large and very prolific school of Siberian botanists should be considered amongst the most important achievements of this self-made pioneer of botanical exploration of Siberia.

No. 3258, VoL. 129] 